\title{
Enhanced Solubilization of Iron and Calcium phosphates by Aspergillus niger by the Addition of Alcohols
}

\author{
Cinthya Babá Barroso ${ }^{1}$ and Ely Nahas ${ }^{2 *}$ \\ ${ }^{1}$ Program of Agropecuary Microbiology/ FCAV-UNESP (in memory). ${ }^{2}$ Department of Crop Production; Faculty of \\ Agronomy and Veterinary Sciences/UNESP; 14884-900 Jaboticabal - SP, Brazil
}

\begin{abstract}
The present study deals with the effect of increased concentrations of alcohols (methanol and ethanol) on the solubilization of $\mathrm{FePO}_{4}$ and $\mathrm{CaHPO}_{4}$ by Aspergillus niger. The efficiency of solubilization (ES) of inorganic phosphates, fungal growth, acid production and $\mathrm{pH}$ variation were determined. The concentrations of alcohols that most favored the solubilization of phosphates were 4\% methanol and 3\% ethanol. The ES of phosphates by the fungus in media containing methanol ranged from 11-96\% and 0.4-87\% for ethanol. The stimulation or inhibition of solubilization was dependent on greater or lesser fungus growth, acid production and decreased pH. These responses were supported by the correlation between the amount of phosphate dissolved and fungal growth $(0.630 * *$ to $0.831 * *)$, the production of acids (0.529* to $0.989 * *)$ and a decrease in $\mathrm{pH}(-0.755 * *$ to $-0.962 * *)$. Thus, the addition of alcohols facilitated insoluble phosphates dissolution during the fungus growth.
\end{abstract}

Key words: Ethanol, methanol, growth, acid production, phosphate solubilization

\section{INTRODUCTION}

Phosphorus is an important element in most metabolic processes and enables the growth of plants; however, the content of soluble phosphate in the soil is very low (Barroso and Nahas 2005; Jain et al. 2010). The solubilization of inorganic phosphates by fungi and bacteria has been studied aiming at the production of soluble phosphate in the soil which would make phosphorous available to the plants growth and increase $\mathrm{P}$ uptake (Vassilev et al. 2006; Chuang et al. 2007; Mamta et al. 2010). Thus, many environmental factors that control microbial solubilization of inorganic phosphates in the growth media and in the soil have been studied (Cerezine et al. 1988; Illmer and Schinner 1992; Wakelin et al. 2004). Inorganic phosphate solubilization is explained by the production of acids, chelation and exchange reactions (Oberson et al. 2001). Organic acids are secreted by the microorganisms and solubilize insoluble phosphate by complexing the cation, which is bound to phosphorus (Whitelaw et al. 1999).

Different fungi have been used for their ability to solubilize the inorganic phosphate (Reyes et al. 2001; Jain et al. 2010). Aspergillus niger is a fungus with a high phosphate solubilization capacity isolated from pasture soil (Barroso and Nahas 2005). This fungus has been extensively studied for its ability to solubilize the inorganic phosphate in culture and in soil (Vassilev et al. 2006) and produce organic acids, mainly citric acid (Max et al. 2010). The organic acids produced by $A$. niger include oxalic, maleic, tartaric, glutamic, citric, acetic, lactic, succinic and

*Author for correspondence: enahas@fcav.unesp.br 
gluconic acids (Illmer and Schinner 1992; Barroso 2006). Citric acid is an intermediary of the tricarboxylic acid cycle and is excreted from the mitochondria with many industrial applications (Karaffa and Kubicek 2003).

The production of citric acid by $A$. niger is influenced by various environmental conditions, such as $\mathrm{pH}$, metal ion nutrition, phosphate concentration, carbon and nitrogen sources. The effect of alcohol on the secretion of acids, mainly citric acid, by fungi has been studied by several authors (Grewal and Kalra 1995; Saha et al. 1999; Yaykash et al. 2005). Saha et al. (1999) demonstrated that methanol and ethanol increased the production of citric acid to $82-85 \%$ compared to the control level of $49 \%$ without the alcohol. The optimum amount of methanol or ethanol to produce acids depends on the microorganism and the composition of media, ranging from 1 to $3 \%$ (Grewal and Kalra 1995). Stimulatory effect of ethanol and methanol on the production or secretion of citric acid by A. niger has also been reported by Hang and Woodams (1998) and Navaratnam et al. (1998). Ethanol and methanol can affect the structural properties of the membranes influencing citric acid excretion. Alcohols enhance the permeability of the cell membrane, allowing the transport of metabolites across the membrane, and thus, influencing citric acid excretion. However, no study has been conducted to evaluate the effect of alcohols on the solubilization of inorganic phosphates.

The present investigation was undertaken to study the effect of alcohols on the solubilization of iron phosphate and calcium phosphate by A. niger.

\section{MATERIALS AND METHODS}

\section{Microorganism}

The fungus Aspergillus niger F111, whose origin has been reported in an earlier study (Barroso and Nahas, 2005), was grown on Sabouraud agar slants for 7 days at $30^{\circ} \mathrm{C}$ and stored at $4^{\circ} \mathrm{C}$ until use.

\section{Culture conditions}

A MS liquid medium containing (g/l) $0.1 \mathrm{NaCl}$, 2.8 glutamic acid, $0.2 \mathrm{KCl}, 0.1 \mathrm{CaCl}_{2} .2 \mathrm{H}_{2} \mathrm{O}, 1.2$ $\mathrm{MgSO}_{4} .7 \mathrm{H}_{2} \mathrm{O}, 10.1$ mannitol, 0.5 yeast extract and $\mathrm{pH}$ 7.0 (Barroso et al. 2006) was used throughout this study. $\mathrm{FePO}_{4}(\mathrm{Fe}-\mathrm{P})$ or $\mathrm{CaHPO}_{4}$
(Ca-P) was added in a quantity of $1.26 \mathrm{~g} \mathrm{PO}_{4}{ }^{3-} \mathrm{L}^{-1}$. Uninoculated controls were maintained under the identical conditions.

\section{Effect of alcohols}

The effect of methanol and ethanol on the solubilization of Fe-P and Ca-P was evaluated by the aseptic addition of 0 to $6 \%(\mathrm{v} / \mathrm{v})$ of alcohols to the culture media. To $250 \mathrm{~mL}$ Erlenmeyer flasks containing $50 \mathrm{~mL}$ MS liquid medium, the above mentioned quantities of $\mathrm{Fe}-\mathrm{P}$ or $\mathrm{Ca}-\mathrm{P}$ were added. After sterilization of the media, increasing concentrations from 0 to $6 \%$ methanol or ethanol ( $\mathrm{v} / \mathrm{v})$ were added and then the $\mathrm{pH}$ was adjusted to 7.0. A $0.5 \mathrm{~mL}$ of a suspension of $A$. niger containing $22.3 \times 10^{6}$ spores $\mathrm{mL}^{-1}$ was inoculated and the flasks were kept without shaking at $30^{\circ} \mathrm{C}$ for 8 days. For control, uninoculated flasks were incubated similarly.

\section{Growth determination}

The culture medium was filtered by using Whatman no. 1 filter paper contained in a Buchner funnel. The mycelium was washed with $0.5 \mathrm{M}$ $\mathrm{NaOH}$ and distilled water. The dry weight of the mycelium was determined after oven drying at $105^{\circ} \mathrm{C}$ for $24 \mathrm{~h}$, cooled in a desiccator and weighed.

\section{Analytical methods}

Soluble phosphate from the filtrate was determined by the Ames method (Ames 1966). The $\mathrm{pH}$ was measured with a Corning glass electrode $\mathrm{pH}$ meter. Titratable acidity was determined by titrating $10 \mathrm{~mL}$ of the filtered broth against a standard solution of $0.02 \mathrm{M} \mathrm{NaOH}$ up to $\mathrm{pH}$ of 7.0, using an automatic titrator (Cerezine et al. 1988). Mannitol was determined using highperformance liquid chromatography (HPLC) (Barroso 2006). The efficiency of solubilization (ES) of $\mathrm{Fe}-\mathrm{P}$ and $\mathrm{Ca}-\mathrm{P}$, in percentage, was determined by the ratio of the mean amount of dissolved phosphate with the total phosphate added to the culture medium.

\section{Statistical analysis}

All the experiments were carried out in triplicate. The data were subjected to the analysis of variance (ANOVA) and comparison of means was made using Tukey's test $(P<0.05)$. Linear correlation coefficients (Pearson's correlation) were calculated for all the properties studied. 


\section{RESULTS}

The results in Figure 1 indicated that increasing concentrations of methanol influenced the growth of $A$. niger in static culture. The solubilization of $\mathrm{FePO}_{4}(\mathrm{Fe}-\mathrm{P})$ increased with up to $4 \%$ methanol yielding $1204.55 \mu \mathrm{g} \mathrm{PO}_{4}{ }^{3-} \mathrm{mL}^{-1}$ and differing significantly $(P<0.05)$ from other treatments. The concentration of phosphate in the uninoculated controls ranged from 18.38 to $24.22 \mu \mathrm{g} \mathrm{PO}_{4}{ }^{3-} \mathrm{mL}^{-1}$ (data not shown). The solubilization decreased sharply to 461.06 and $137.58 \mu \mathrm{g} \mathrm{PO}_{4}{ }^{3-} \mathrm{mL}^{-1}$ at 5 and $6 \%$ methanol, respectively. The addition of $3 \%$ methanol resulted in the most enhanced fungus growth with an output of $4.46 \mathrm{mg} \mathrm{mL}^{-1}$ mycelium dry weight, and the $\mathrm{pH}$ of the culture medium decreased significantly $(P<0.05)$ to 1.77 (Fig. 1$)$. The highest production of acidity was found in the culture medium supplemented with $4 \%$ methanol, with $2.74 \mathrm{mg} \mathrm{mL}^{-1}$ acids being secreted (Fig. 1).

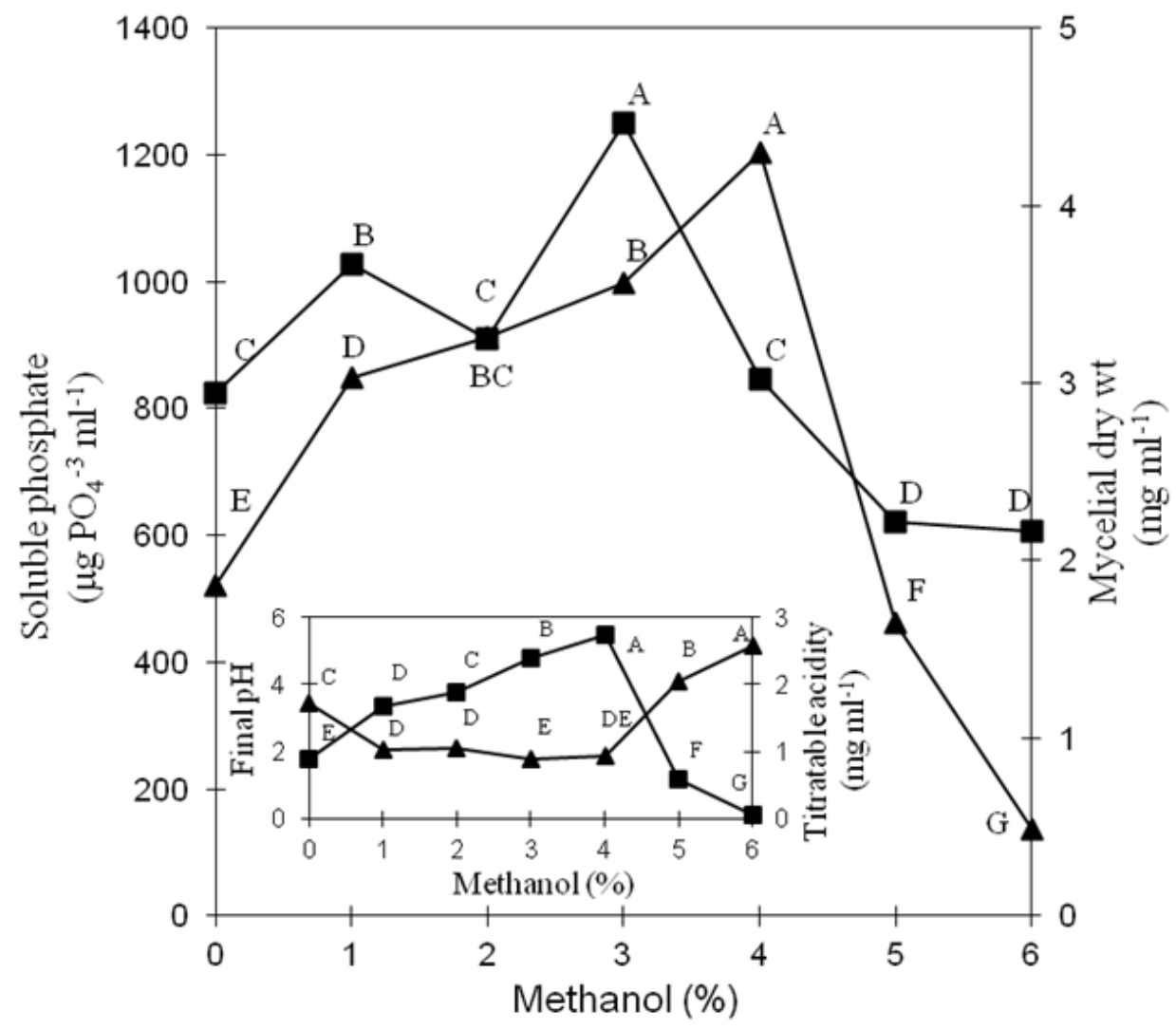

Figure 1 - Effect of increasing concentrations of methanol on the Aspergillus niger growth and solubilization of $\mathrm{FePO}_{4}$. Values followed by the same letter(s) show no significant differences $(P<0.05)$. $(\mathbf{\Delta})$ soluble phosphate; final $\mathrm{pH} ; \mathbf{\square})$ mycelial dry weight; titratable acidity.

As shown in Figure 2, A. niger produced higher amounts of solubilized Fe-P, $1098.51 \mu \mathrm{g} \mathrm{PO}_{4}{ }^{3-} \mathrm{mL}^{-1}$ and acid $3.19 \mathrm{mg} \mathrm{mL}^{-}$with $3 \%$ ethanol. The growth of the fungus, was maximum $\left(7.25 \mathrm{mg} \mathrm{mL}^{-}\right.$ ${ }^{1}$ dry weight) with the addition of $1 \%$ ethanol (Fig. 2). The final $\mathrm{pH}$ of the culture medium with $3 \%$ ethanol decreased considerably to 2.08 (Fig. 2). There was no significant difference in the solubilization of Ca-P in the media with the addition of 1 to $6 \%$ methanol in spite of increased amounts of solubilized phosphate, that is, from 685.62 to $872.47 \mu \mathrm{g} \mathrm{PO}_{4}{ }^{3-} \mathrm{mL}^{-1}$ (Fig. 3). The growth of the fungus was maximum $\left(7.66 \mathrm{mg} \mathrm{mL}^{-}\right.$ ${ }^{1}$ dry weight) with $3 \%$ methanol, which resulted in drop of the $\mathrm{pH}$ to 2.1 and acid production as 2.39 $\mathrm{mg} \mathrm{mL}^{-1}$ (Fig. 3). 


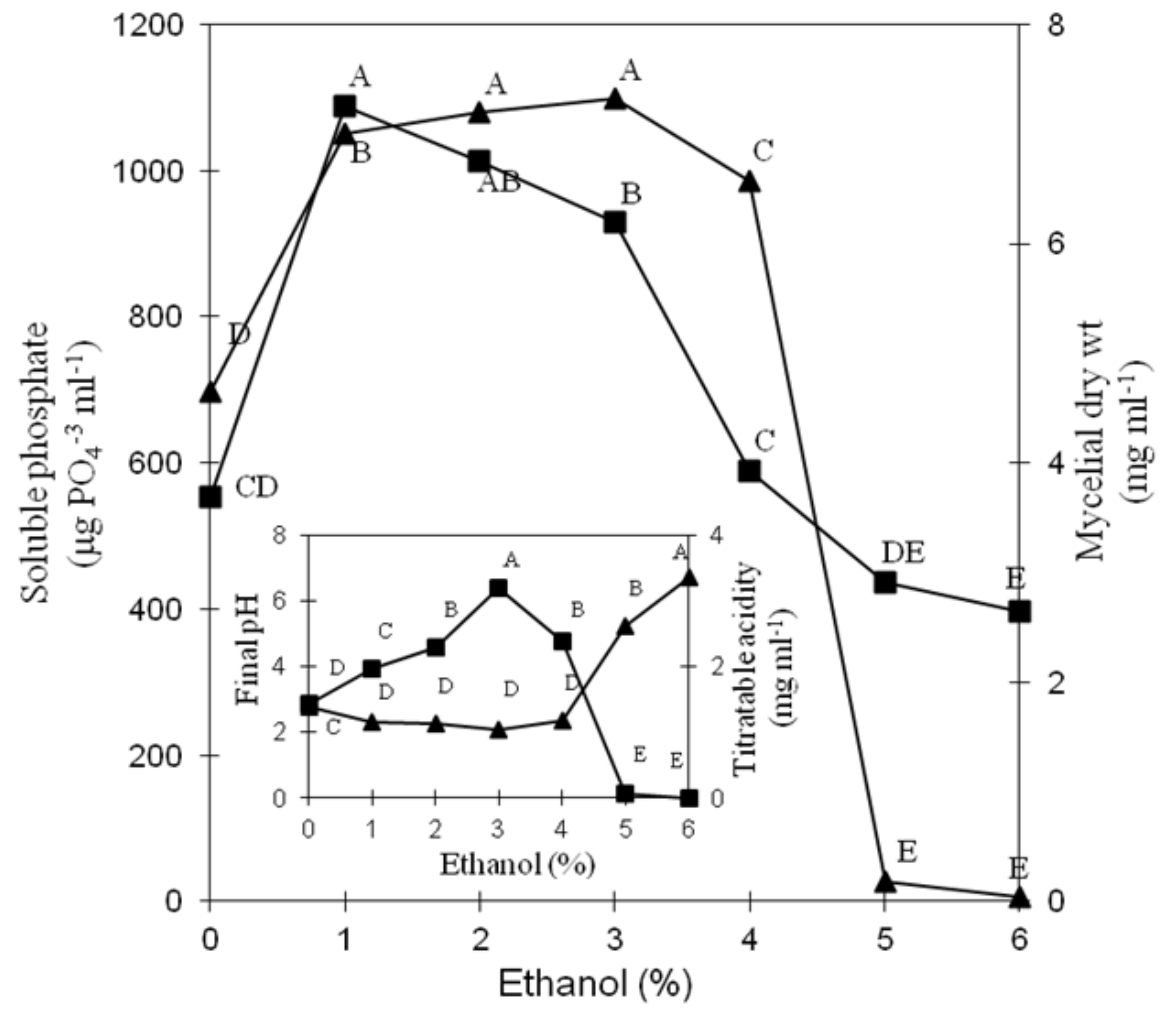

Figure 2 - Effect of increasing concentrations of ethanol on the Aspergillus niger growth and solubilization of $\mathrm{FePO}_{4}$. Values followed by the same letter(s) show no significant differences $(P<0.05)$. ( $\mathbf{Q})$ soluble phosphate, final $\mathrm{pH} ;(\boldsymbol{\Delta})$ mycelial dry weight, titratable acidity.

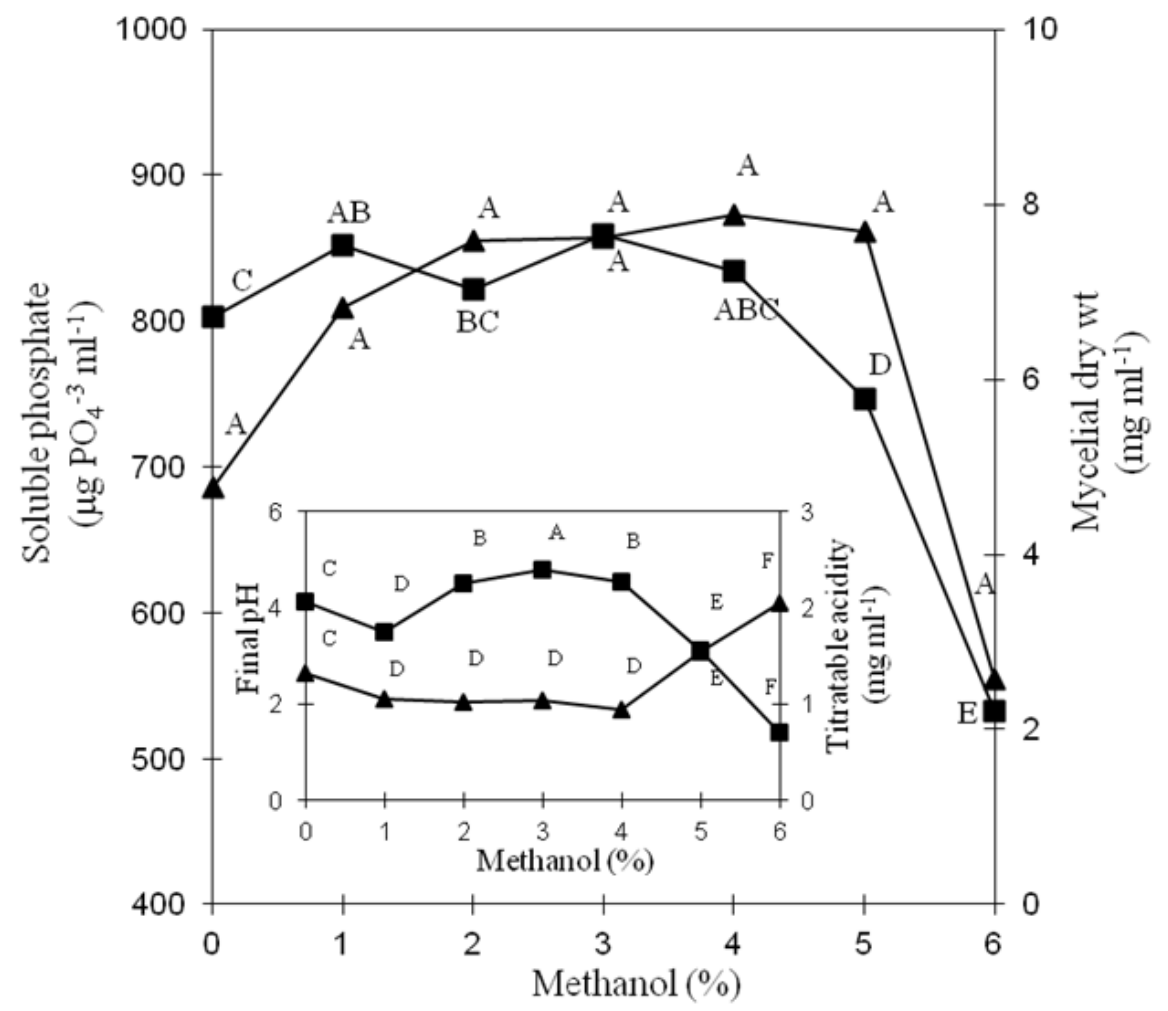

Figure 3 - Effect of increasing concentrations of methanol on the Aspergillus niger growth and solubilization of $\mathrm{CaHPO}_{4}$. Values followed by the same letter(s) show no significant differences $(P<0.05)$. ( $\boldsymbol{\Delta})$ soluble phosphate, final $\mathrm{pH}$; ( $\square$ ) mycelial dry weight, titratable acidity. 
The addition of $3 \%$ ethanol increased the solubilization of $\mathrm{Ca}-\mathrm{P}$ by $A$. niger with the production of $901.22 \mu \mathrm{g} \mathrm{PO}_{4}{ }^{3-} \mathrm{mL}^{-1}$; however, no significant difference was found between the media with 0,1 and $3 \%$ ethanol (Fig. 4). Highest mycelium growth $(P<0.05)$ was in the medium with $2 \%$ ethanol. The $\mathrm{pH}$ decreased from 7.0 to
1.89 in the medium with $1 \%$ ethanol, but increasing the concentration of ethanol tended to increase the $\mathrm{pH}$ value (Fig. 4). The amount of acidity produced $\left(8.35 \mathrm{mg} \mathrm{mL}^{-1}\right)$ was highest in the medium containing $3 \%$ ethanol, differing significantly from the other treatments (Fig. 4).

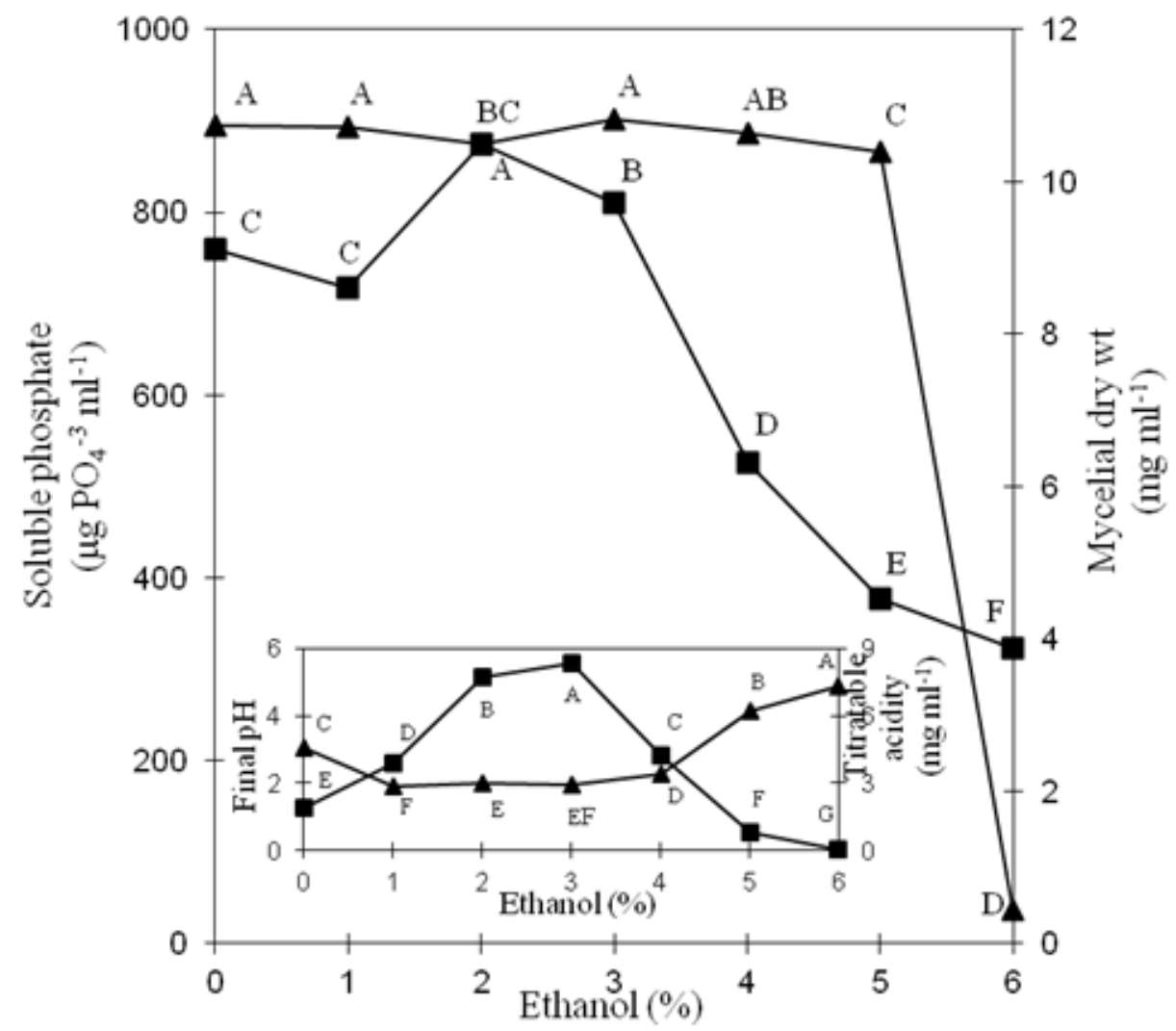

Figure 4 - Effect of increasing concentrations of ethanol on the Aspergillus niger growth and solubilization of $\mathrm{CaHPO}_{4}$. Values followed by the same letter(s) show no significant differences $(P<0.05)$. ( $\boldsymbol{\Delta})$ soluble phosphate, final $\mathrm{pH}$; $(\boldsymbol{\square})$ mycelial dry weight, titratable acidity.

The efficiency of solubilization (ES) of phosphates by the fungus in the media containing methanol ranged from 11 to $96 \%$ and 0.4 to $87 \%$ with ethanol (Table 1). The increase of ES in the optimal concentration of methanol was $15 \%$ (Ca$\mathrm{P})$ and $54 \%(\mathrm{Fe}-\mathrm{P})$ in relation to the control and with ethanol was $0.5 \%$ (Ca-P) and $32 \%(\mathrm{Fe}-\mathrm{P})$.

The amount of mannitol, added as a carbon source, decreased by $62 \%$ in relation to the control (without alcohol) in the medium containing $2 \%$ methanol and by $36 \%$ in the medium with $3 \%$ ethanol, followed by an increase in both the media (Fig. 5).

The variables were highly correlated with each other, except for phosphate that was not correlated with mycelial growth in the media added with $\mathrm{Ca}-$ $\mathrm{P}$ and increasing concentration of ethanol (Table 2).

All the correlations between the variables were positives, except that related to final $\mathrm{pH}$ which are negative. 
Table 1 - Efficiency of solubilization (\%) of $\mathrm{FePO}_{4}$ and $\mathrm{CaHPO}_{4}$ by the fungus Aspergillus niger in media added with enhanced concentrations of alcohols.

\begin{tabular}{ccccc}
\hline Alcohol & Methanol & Methanol & Ethanol & Ethanol \\
\hline$(\%)$ & $\mathrm{FePO}_{4}$ & $\mathrm{CaHPO}_{4}$ & $\mathrm{FePO}_{4}$ & $\mathrm{CaHPO}_{4}$ \\
\hline 0 & $41.36 \pm 0.24 \mathrm{E}$ & $54.41 \pm 0.32 \mathrm{C}$ & $55.27 \pm 0.69 \mathrm{D}$ & $71.03 \pm 0.41 \mathrm{~A}$ \\
1 & $67.45 \pm 0.20 \mathrm{D}$ & $64.23 \pm 0.19 \mathrm{~B}$ & $83.45 \pm 0.80 \mathrm{D}$ & $70.90 \pm 0.21 \mathrm{~A}$ \\
2 & $72.42 \pm 0.40 \mathrm{C}$ & $67.83 \pm 0.37 \mathrm{~A}$ & $85.62 \pm 0.55 \mathrm{~A}$ & $69.39 \pm 0.38 \mathrm{BC}$ \\
3 & $79.29 \pm 0.24 \mathrm{~B}$ & $68.05 \pm 0.21 \mathrm{~A}$ & $87.18 \pm 0.12 \mathrm{~A}$ & $71.53 \pm 0.22 \mathrm{~A}$ \\
4 & $95.60 \pm 0.55 \mathrm{~A}$ & $69.24 \pm 0.40 \mathrm{~A}$ & $78.26 \pm 0.75 \mathrm{C}$ & $70.30 \pm 0.41 \mathrm{AB}$ \\
5 & $36.59 \pm 0.32 \mathrm{~F}$ & $68.32 \pm 0.59 \mathrm{~A}$ & $2.15 \pm 0.21 \mathrm{E}$ & $68.72 \pm 0.59 \mathrm{C}$ \\
6 & $10.92 \pm 0.21 \mathrm{G}$ & $44.00 \pm 0.84 \mathrm{D}$ & $0.40 \pm 0.27 \mathrm{E}$ & $2.94 \pm 0.06 \mathrm{D}$ \\
\hline
\end{tabular}

Letters on the same column do not differ (Tukey test. $P<0.05$ ). Values are averages \pm SD (Standard Deviation).

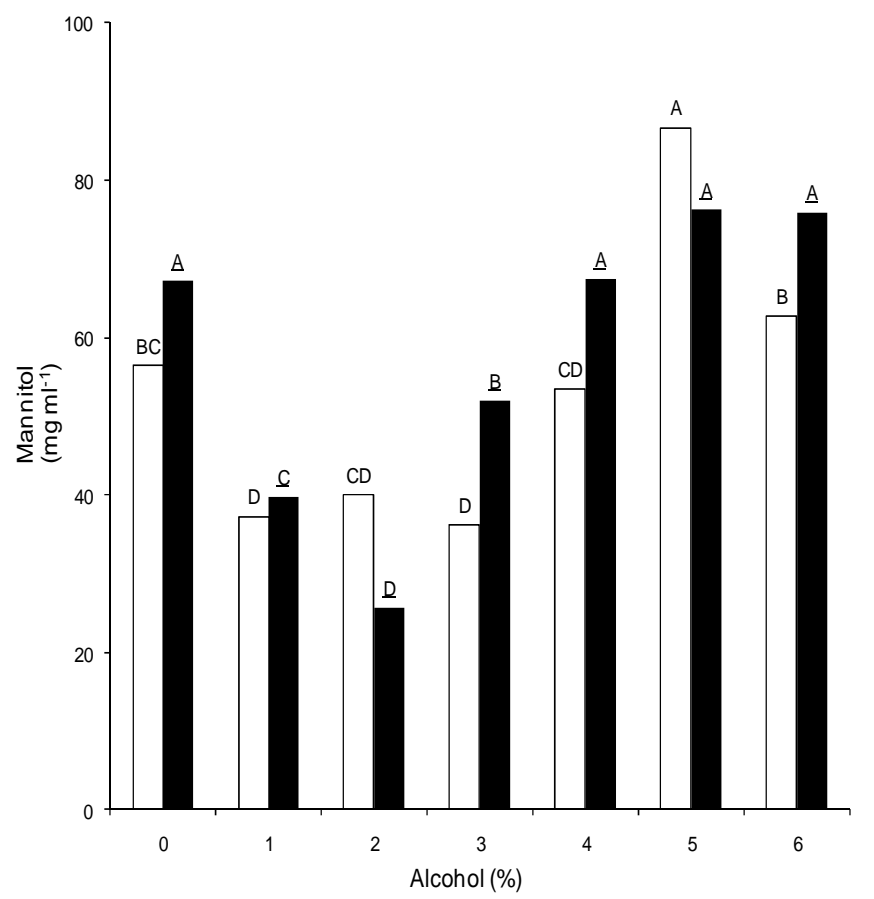

Figure 5 - Residual mannitol contents of the culture media added with alcohols and inoculated with Aspergillus niger. Columns followed by the same letter(s) (underlined or no) show no significant differences $(P<0.05)$. ( $\square)$ ethanol; $(\square)$ methanol.

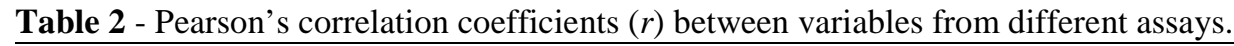

\begin{tabular}{lcccc}
\hline \multirow{2}{*}{ Variables } & \multicolumn{2}{c}{ Methanol } & \multicolumn{2}{c}{ Ethanol } \\
\cline { 2 - 5 } & $\mathbf{F e P O}_{\mathbf{4}}$ & $\mathbf{C a H P O}_{\mathbf{4}}$ & $\mathbf{F e P O}_{\mathbf{4}}$ & $\mathbf{C a H P O}_{4}$ \\
\hline Phosphate x mycelial dry wt. & $0.702^{* *}$ & $0.813^{* *}$ & $0.831^{* *}$ & $0.630^{\mathrm{NS}}$ \\
Phosphate x final pH & $-0.962^{* *}$ & $-0.809^{* *}$ & $-0.961^{* *}$ & $-0.755^{*}$ \\
Phosphate x titratable acidity & $0.989^{* *}$ & $0.757^{* *}$ & $0.957^{* *}$ & $0.529^{*}$ \\
Mycelial dry wt. x final pH & $-0.830^{* *}$ & $-0.959^{* *}$ & $-0.747^{* *}$ & $-0.843^{* *}$ \\
Mycelial dry wt. x titratable acidity & $0.744^{* *}$ & $0.920^{* *}$ & $0.746^{* *}$ & $0.805^{* *}$ \\
Final pH x titratable acidity & $-0.948^{* *}$ & $-0.926^{* *}$ & $-0.914^{* *}$ & $-0.843^{* *}$ \\
\hline
\end{tabular}

Phosphate solubilized $=\mu \mathrm{g} \mathrm{PO}_{4}^{-3} \mathrm{~mL}^{-1} ;$ Mycelial dry $\mathrm{wt}=\mathrm{mg} \mathrm{mL}^{-1}$; Titratable acidity $=\mathrm{mg} \mathrm{mL}^{-1} .\left(^{*}\right) \mathrm{P}<0.05 ;(* *) \mathrm{P}<0.01 ; \mathrm{N}$ $=21$. 


\section{DISCUSSION}

The results presented here clearly showed that the amount of soluble $\mathrm{P}$ could be increased significantly in comparison to control (without alcohols) in the growth media with the addition of increasing concentrations of alcohols up to an optimum. The following conclusions could be drawn: the highest efficiency of solubilization (ES) of $\mathrm{FePO}_{4}(\mathrm{Fe}-\mathrm{P})$ and $\mathrm{CaHPO}_{4}(\mathrm{Ca}-\mathrm{P})$ was in the media containing $4 \%$ methanol and $3 \%$ ethanol, respectively; increasing the concentration of alcohols (0 to 6\%) showed an improvement in the ES from 0.5 to $32 \%$ (3\% ethanol) and from 14 to $54 \%$ (4\% methanol) of Fe-P and Ca-P solubilized in relation to the control ( $0 \%$ alcohol). The alcohols used must have influenced the metabolism of mannitol, used as a carbon source, and thus also affected the growth of the fungus and consequently the release of organic acids in the media. A significant and positive correlation ranging from $r=0.74 * *$ to $r=0.92 * *$ between the titratable acidity and the mycelium dry weight confirmed this conclusion (Table 2).

Depending of the concentration, alcohols could stimulate or inhibit the secretion of organic acids. No effects of the use of alcohols on the solubilization of Fe-P and Ca-P have been reported in the literature. In this study, the optimal concentration for Fe-P was 3\% ethanol and 4\% methanol for Ca-P. This was in agreement with Yaykash et al. (2005), who observed increased production of citric acid in the medium supplemented with $3 \%$ ethanol and $4 \%$ methanol. Similarly, Hang and Woodams (1998) found increased excretion of citric acid at concentrations up to $3 \%$ methanol. Under optimized conditions, both methanol and ethanol can increase the cell membrane permeability of $A$. niger, thus releasing citric acid (Nadeem et al. 2010). However, Navaratnam et al. (1998) reported that methanol did not improve the permeability of the membrane to citric acid, but could be used as carbon source in the presence of glucose. This was probably not the mechanism observed in the present study, because increased amounts of alcohols inhibited the production of organic acids and mineral phosphate solubilization.

Beyond the optimum concentration of alcohols, titratable acidity, sugar consumption and dry mass decreased, while $\mathrm{pH}$ increased. A similar effect was reported with respect to acid production (Hang and Woodams 1998). Chaudhary et al.
(1978) also found that high concentrations of ethanol or methanol decreased A. niger growth and the production of citric acid. This inhibitory effect could be due to high concentration of alcohols, which denatured the cellular proteins and altered the cell membrane. Grisham and Barnett (1972) attributed the decline in citric acid production to the higher concentrations of alcohols, which inhibited the membrane enzymes. Haq et al. (2003) reported that the decrease in citric acid production was due to a change in fungal metabolism and mycelial morphology. In fact, this mechanism is complex and many physiological and biochemical effects induced by alcohols may change the permeability of the membrane and the enzymes involved in the absorption of nutrients and secretion of citric acid. It has been suggested that the fatty acid composition in bacteria changes in response to physical and chemical interactions between high concentrations of alcohols and cytoplasmic membrane lipids (Ingram 1976).

The mechanism of solubilization of inorganic phosphates depends on various factors as reported by several authors (Reyes et al. 2001; Nahas 2007; Scervino et al. 2010). However, the results of this study clearly demonstrated that the solubility of $\mathrm{Fe}-\mathrm{P}$ and $\mathrm{Ca}-\mathrm{P}$ was dependent on the fungus growth, total acid production and $\mathrm{pH}$. This conclusion could be demonstrated by the positive correlation between the amount of solubilized phosphate and the titratable acidity $(0.529 *$ to $0.989^{* *}$ ) (Table 2). These results were in accordance with other studies showing dependence of phosphate solubilization to the production of acids (El-Azouni 2008; Ogbo et al. 2010). For example, similar to the present results, Bojinova et al. (2008) found correlation coefficients, which ranged from 0.8 to 0.98 for the solubilization of Morocco phosphorite by $A$. niger in culture medium.

Previous studies have reported that the amount of dissolved phosphate was related to the decrease in $\mathrm{pH}$ of the growth medium (Reddy et al. 2002; Seshadri et al. 2004; Bojinova et al. 2008). Rinu and Pandey (2010) reported a correlation, which ranged from -0.907 to -0.983 between the decline in $\mathrm{pH}$ and phosphate solubilization. In the present study, the negative correlation coefficients ranged from $-0.755^{* *}$ to $-0.962 * *$. The decrease in $\mathrm{pH}$ could be explained by increased secretion of acid by $A$. niger during the growth as shown by the significant correlation ranging from $-0.843 * *$ to $0.948 * *$ observed in this work. This conclusion 
was consistent with Saber et al. (2009), who obtained a correlation of -0.81 between the decrease in $\mathrm{pH}$ and acid production.

In conclusion, iron (Fe-P) and calcium (Ca-P) phosphates were solubilized by $A$. niger grown in the medium supplemented with increasing concentrations of methanol or ethanol. The solubilization of phosphate increased on supplementation with up to $4 \%$ methanol and $3 \%$ ethanol and then decreased. The efficiency of solubilization (ES) of the phosphates was higher for methanol than ethanol. ES of Fe-P was higher than Ca-P. A. niger growth and acid production increased up to the optimal concentrations of solubilized phosphates and then declined.

\section{ACKNOWLEDGEMENTS}

The work was supported by FAPESP (Fundação de Amparo à Pesquisa do Estado de São Paulo). We gratefully acknowledge research fellowships from FAPESP (C.B.Barroso) and CNPq (Conselho Nacional de Desenvolvimento Científico e Tecnológico (E.Nahas).

\section{REFERENCES}

Ames BN. Assay of inorganic phosphate and phosphatases. Meth Enzymol. 1966; 8: 115-116.

Barroso, CB. Produção de pellets livres e imobilizados e mecanismo de solubilização de fosfatos inorgânicos por Aspergillus niger F111 [Dr. Thesis]. Jaboticabal, SP, Brazil: Universidade Estadual Paulista (UNESP); 2006.

Barroso CB, Pereira GT, Nahas E. Solubilization of $\mathrm{CaHPO}_{4}$ and $\mathrm{AlPO}_{4}$ by Aspergillus niger in culture media with different carbon and nitrogen sources. Braz J Microbiol. 2006; 37: 434-438.

Barroso CB, Nahas E. The status of soil phosphate fractions and the ability of fungi to dissolve hardly soluble phosphates. Appl Soil Ecol. 2005; 29: 73-83.

Bojinova D. Velkova R, Ivanova R. Solubilization of Morocco phosphorite by Aspergillus niger. Biores Technol, 2008; 99: 7348-7353.

Cerezine PC, Nahas E., Banzatto, DA. Soluble phosphate accumulation by Aspergillus niger from fluorapatite. Appl Microbiol Biotechnol. 1988; 29: 501- 505.

Chaudhary K., Ethiraj S, Lakshminarayana K, Tauro P. Citric acid production from Indian cane molasses by Aspergillus niger under solid state fermentation conditions. J Ferment. 1978; 56: 554-557.
Chuang CC, Kuo YL, Chao CC, Chao WL. Solubilization of inorganic phosphates and plant growth promotion by Aspergillus niger. Biol Fertil Soils. 2007; 43: 575-584.

El-Azouni IM. Effect of phosphate solubilizing fungi on growth and nutrient uptake of soybean (Glycine max L.) plants. J Appl Sci Res. 2008, 4: 592-598.

Grewal HS, Kalra KL. Fungal production of citric acid. Biotechnol Adv. 1995; 13: 209-234.

Grisham CM, Barnett RE. The interrelationship of membrane and protein structure in the functioning of the $\left(\mathrm{Na}^{+}+\mathrm{K}^{+}\right)$-activated ATPase. Biochim Biophys Acta. 1972; 266: 613-624.

Hang YD, Woodams EE. Production of citric acid from corncobs by Aspergillus niger. Biores Technol. 1998; 65: 251-253.

Haq IU, Ali S, Qadeer MA, Iqbal J. Stimulatory effect of alcohols (methanol and ethanol) on citric acid productivity by a 2-deoxy D-glucose resistant culture of Aspergillus niger GCB-47. Biores Technol. 2003; 86: 227-233.

Illmer P, Schinner F. Solubilization of inorganic phosphates by microorganisms isolated from forest soils. Soil Biol Biochem. 1992; 24: 389-395.

Ingram LO. Adaptation of membrane lipids to alcohols. J Bacteriol. 1976; 125: 670-678.

Jain R, Saxena J, Sharma V. The evaluation of free and encapsulated Aspergillus awamori for phosphate solubilization in fermentation and soil-plant system. Applied Soil Ecol. 2010; 46: 90-94.

Karaffa L, Kubicek CP. Aspergillus niger citric acid accumulation: do we understand this well working black box? Appl Microbiol Biotechnol. 2003; 61: 189-196.

Mamta, Rahic P, Pathaniad V, Gulati A, Singh B, Bhanwra RK, Tewari R. Stimulatory effect of phosphate-solubilizing bacteria on plant growth, stevioside and rebaudioside-A contents of Stevia rebaudiana Bertoni. Appl Soil Ecol. 2010; 46: 222229.

Max B, Salgado JM, Rodríguez N, Cortés S, Converti A, Dominguez JM. Biotechnological production of citric acid. Braz J Microbiol. 2010; 41: 862-875.

Nadeem A, Syed Q, Baig S, Irfan M, Nadeem M. Enhanced production of citric acid by Aspergillus niger M-101 using lower alcohols. Turkish J Biochem. 2010; 35: 7-13.

Nahas E. Phosphate solubilizing microorganisms: Effect of carbon, nitrogen, and phosphorus sources. In: Velázquez E, Rodríguez-Barrueco C, editors. First International Meeting on Microbial Phosphate Solubilization. Salamanca, Spain, Springer, Book Series: Development in Plant and Soil Sciences. 2007; 102: 111-115.

Navaratnam P, Arasaratnam V, Balasubramaniam K. Channelling of glucose by methanol for citric acid production from Aspergillus niger. World J Microbiol Biotechnol. 1998; 14: 559-563. 
Oberson A, Friesen DK, Rao IM, Buhler S, Frossard E. Phosphorus transformations in an oxisol under contrasting land-use system: the role of the microbial biomass. Plant Soil. 2001; 237: 197-210.

Ogbo FC. Conversion of cassava wastes for biofertilizer production using phosphate solubilizing fungi. Biores Technol. 2010; 101: 4120-4124.

Reddy M, Kumar S, Babita K, Reddy MS. Biosolubilization of poorly soluble rock phosphates by Aspergillus tubingensis and Aspergillus niger. Biores Technol. 2002; 84: 187-189.

Reyes I, Baziramakenga R, Bernier L, Antoun H. Solubilization of phosphate rocks and minerals by a wild-type strain and two UV-induced mutants of Penicillium rugulosum. Soil Biol Biochem. 2001; 33: 1741-1747.

Rinu K, Pandey A. Slow and steady phosphate solubilization by a psychrotolerant strain of Paecilomyces hepiali (MTCC 9621). World J Microbiol Biotechnol. 2010; 26: 1-8.

Saber WIA, Ghanem K M, El-Hersh MS. Rock phosphate solubilization by two isolates of Aspergillus niger and Penicillium sp. and their promotion to mung bean plants. Res J Microbiol. 2009; 4: 235-250.

Saha ML, Sakai Y, Takahashi F. Citric acid fermentation by magnetic drum contactor: use of methanol and ethanol for higher production. J. Biosci Bioeng. 1999; 87: 394-396.

Scervino JM, Mesa MP, Mônica ID, Recchi M, Moreno NS, Godeas A. Soil fungal isolates produce different organic acid patterns involved in phosphate salts solubilization. Biol Fertil Soils, 2010; 46: 755-763.
Seshadri S, Ignacimuthu S, Lakshminarasimhan C. Effect of nitrogen and carbon sources on the inorganic phosphate solubilization by different Aspergillus niger strains. Chem Eng Commun. 2004; 191: 1043-1052.

Vassilev N, Medina A, Azcón R, Vassileva M. Microbial solubilization of rock phosphate on media containing agro-industrial wastes and effect of the resulting products on plant growth and $\mathrm{P}$ uptake. Plant Soil. 2006; 287: 77-84.

Wakelin SA, Warren RA, Harvey PR, Ryder M H. Phosphate solubilization by Penicillium spp. closely associated with wheat roots. Biol Fertil Soils, 2004; 40: 36-43.

Whitelaw MA, Harden TJ, Helyar KR. Phosphate solubilisation in solution culture by the soil fungus Penicillium radicum. Soil Biol Biochem. 1999; 32: 655-665.

Yaykash KO, Demirel G, Yasar A. Influence of alcohols on citric acid production by Aspergillus niger A-9 entrapped in polyacrylamide gels. J. Food Eng. 2005; 70: 518-522. 


\section{PAGINA \\ EM BRANCO}

